Artikkelen analyserer "ressursdimensjonen" innenfor retten til selubestemmelse i Vest-Sahara. Den viser at dagens utvinning ikke tar hensyn til interessene til saharawiene, og at nye lisensavtaler med saharawiske myndigheter innenfor olje og gass uttrykker en mer konstruktiv tilnærming fra internasjonale selskaper.

\title{
Fisk, olje og folkerett i Vest-Sahara
}

Hans Morten Haugen, dr. juris (Universitetet i Oslo), er førsteamanuensis ved Diakonhjemmet Høgskole og har arbeidet med Vest-Sahara gjennom Støttekomiteen for Vest-Sahara siden 1993. Han har også arbeidet ved Mellomkirkelig råd for Den norske kirke (1996-2002) og i Jerusalem for Kirkens Nødhjelp (2005-06). 
TEKST: Hans Morten Haugen

VEST-SAHARA ER OFFER for en ufullstendig avkoloniseringsprosess, der prosessen fram mot en avkolonisering ble avbrutt som følge av Marokko og Mauretanias invasjon i I975-76 og Marokkos fortsatte okkupasjon av størstedelen av Vest-Sahara. Anslagsvis 25 prosent av territoriet - bak den minelagte marokkanske muren - kontrolleres av Front Polisario ("Den folkelige fronten for frigjøring av Saguia el-Hamra og Rio del Oro" - de to landområdene som utgjør territoriet Vest-Sahara). Prinsippet om at tidligere kolonigrenser skal respekteres ble i I964 nedfelt av Organisasjonen for afrikansk enhet (OAU; nå: Den afrikanske unionen, AU).

Selv om det er eksempler på at FN har omtalt territoriet som okkupert og bedt Marokko om å avslutte sin okkupasjon, ${ }^{\mathrm{I}}$ er det mest vanlig å omtale Vest-Sahara som et "ikke-selvstyrt område". FN-pakten, artikkel 73 og 74, regulerer administrasjonen av ikke-selvstyrte områder.

Vest-Sahara har en utstrekning som gjør territoriet til det største ikke-selvstyrte området i verden, og besitter ressurser som er strategisk og økonomisk viktige for Marokko.

Ikke-selvstyrte områder forvaltes av en administrasjonsstat på vegne av FN. Rettighetene over naturressurser skal sikres for folket i slike ikke-selvstyrte områder. Dette innebærer at det ikke er forbudt å utvinne ressurser fra slike selvstyrte områder. Det sentrale er hvordan ressursuthentingen foregår. Bare dersom uthenting av naturressurser skjer i samsvar med det ikke-selvstyrte folkets ønsker, og for å bidra til å oppfylle FN-paktens bestemmelser, inklusive "å utvikle selvstyre" for disse folkene (FN-pakten artikkel 73(b)), er en slik uthenting av naturressurser i samsvar med folkeretten.

I Vest-Sahara har fortsatt Spania ansvaret de jure for det ikke-selvstyrte området. Marokko invaderte i I975 Vest-Sahara, i strid med internasjonal rett, og utøver myndighet de facto i store deler av den tidligere spanske kolonien. Den afrikanske unionens anerkjennelse av Vest-Sahara har medført at Marokko har meldt seg ut av organisasjonen.

Denne artikkelen vil gjennom en juridisk tolkning finne svar på om det saharawiske folket får sine rettigheter ivaretatt i samsvar med internasjonal rett. Med utgangspunkt i ressursdimensjonen av folkenes rett til selvbestemmelse, som er regulert i artikkel I, paragraf 2 i FNs Konvensjon om sivile og politiske rettigheter og FNs Konvensjon om økonomiske, sosiale og kulturelle rettigheter, spør artikkelen 
om ressursutvinningen skjer i samråd med det saharawiske folket og i samsvar med deres ønsker. Vekten vil ligge på avtaler knyttet til fiskeressurser og avtaler knyttet til olje- og gassressurser.

\section{FN-konvensjoner og -resolusjoner}

FN-paktens artikkel 73(b) sier at at medlemsland som "har eller som påtar seg ansvaret for administrasjonen av områder hvis folk ennå ikke har nådd selvstyre i fullt mål” plikter "å utvikle selvstyre, ta rimelig hensyn til folkenes politiske ønskemål og å støtte dem i den gradvise utvikling av frie politiske institusjoner ..."

Artikkel 73 i FN-pakten bruker begrepene "innbyggerne" ("inhabitants") og "folk" ("peoples"). Disse to er nødvendigvis ikke det samme. Det er presisert i FN-resolusjoner (se under) at det er "folk", inklusive urfolk, som har rettigheter til naturressursene $i$ et ikke-selvstyrt område. Innbyggere er et videre begrep og omfatter også dem som ikke opprinnelig stammer fra området. Det er rimelig å forså at alle innbyggernes rettigheter skal respekteres, men at det "folket" som tradsjonelt har hatt tilhørighet til et ikkeselvstyrt områder, har sterkere rettigheter hva gjelder råderetten over naturressursene.

For det andre er ressursdimensjonen knyttet til retten til selvbestemmelse regulert i to paragrafer av artikkel i i FNs konvensjon om økonomiske, sosiale og kulturelle rettigheter og FNs Konvensjon om sivile og politiske rettigheter. Paragraf 2 sier at "Alle folk kan for sine egne formål fritt råde over sine naturrikdommer og -forekomster ..." Paragraf 3 gjelder spesifikt for stater som har ansvaret for administrasjonen av ikke-selvstyrte områder. Disse "skal arbeide for å virkeliggjøre folkenes selvbestemmelsesrett, og skal respektere denne rett $i$ overensstemmelse med bestemmelsene $i$ De forente nasjoners pakt." Denne bestemmelsen bekrefter innholdet i FN-pakten, men konvensjonene regulerer i større grad og i større detalj staters atferd enn hva tilfellet er for FN-pakten.

Dette er bindende bestemmelser siden FN-pakten er bindende for alle FNs medlemsstater, og siden Marokko og Spania begge er part i de to konvensjonene. I tillegg finnes en rekke ikke-bindende resolusjoner. For det første finnes resolusjon I5I4 (XV) om tidligere kolonifolks rett til selvbestemmelse, vedtatt i iو60.²

For det andre utdyper resolusjon I54I (XV) pliktene for staten som har ansvaret for administrasjonen av ikke-selvstyrte områder, og opplister prinsippene som må følges for de tre mulige utfall for et ikkeselvstyrt område: Full innlemmelse, assosiering eller full uavhengighet. ${ }^{3}$ Eksempelvis har Puerto Rico frivillig valgt å bli en "avhengig stat" av USA (altså en form for assosiering).

For det tredje finnes resolusjon 1803 (XVII) fra I962 om "Permanent suverenitet over naturressurser". Her gis like rettigheter til "nasjoner" og "folk", jamfør avsnitt 8 som pålegger stater å "respektere suvereniteten til folk og nasjoner over deres naturrikdommer og ressurser."

For det fjerde sier resolusjon III fra FNs Havrettskonferanse fra I982:

In the case of a territory whose people have not attained full independence or other self-governing status recognized by the United Nations, or a territory under colonial domination, provisions concerning rights and interests under the Convention shall be implemented for the 
benefit of the people of the territory with a view to promoting their well-being and development.

Vedrørende fiske, sier Artikkel 6I, paragraf I i Havrettskonvensjonen at "Kyststaten skal fastsette den tillatte fangst av de levende ressurser i sin eksklusive økonomiske sone." Vedrørende oljeleting, sier artikkel 77, paragraf I at rettigheter til både leting ("exploring") og utvinning ("exploiting") ligger til kyststaten. Begrepet "kyststaten", i disse tilfeller, må forstås å vise til saharawienes egen stat, Den saharawiske arabiske demokratiske republikk (SADR), ${ }^{4}$ som i dag bare kontrollerer de østlige delene av Vest-Sahara, men der det saharawiske folkets interesser skal sikres i implementeringen av Havrettskonvensjonen. Dette prinsippet var sentralt for Det etiske råd under Statens Pensjonsfond Utland, i anbefalingen om uttrekk. ${ }^{5}$

I tillegg har FNs "Charter of Economic Rights and Duties of States" fra 1974 nedfelt at: "No State has the right to promote or encourage investments that may constitute an obstacle to the liberation of a territory occupied by force."

Vi ser altså at både konvensjoner og resolusjoner har bekreftet prinsippet om selvbestemmelse for folk i ikke-selvtyrte områder, og at dette prinsippet også omfatter råderetten over naturressursene.

\section{Konkretisering av disse prinsippene}

Utgangspunktet for en rettslig tilnærming til hvordan Vest-Sahara skal styres - inklusive kontroll over naturressurser - må starte med erkjennelsen av at Vest-Sahara er et ikke-selvstyrt område, hvor Spania fortsatt har ansvar over administrasjonen. Samtidig er de marokkanske investerin- gene gjort hovedsakelig i og rundt byen El Aaiún for å fasilitere utvinningen av naturressursene, et hinder for frigjøring av et territorium okkupert ved makt.

Disse investeringene bidrar til å integrere den saharawiske økonomien sterkere inn $\mathrm{i}$ den marokkanske, en integrasjon som er vurdert å ha "potensielt enorme implikasjoner for den marokkanske økonomien."

$$
\begin{aligned}
& \text { Det er "folk", inklusive urfolk, } \\
& \text { som har rettigheter til ressurser } \\
& \text { i et ikke-selvstyrt område. }
\end{aligned}
$$

som er aktive i naturressursvirksomhet i Vest-Sahara, er kontrollert av den marokkanske politiske og militære eliten.

Den viktigste bestemmelsen er de to paragrafene i artikkel I av FNs konvensjon om økonomiske, sosiale og kulturelle rettigheter og FNs Konvensjon om sivile og politiske rettigheter, som gir kollektive rettigheter til "folk". Vi skal se kort på anvendelsesområdet for denne paragrafen, drøfte om saharawiene kan ha rettigheter etter denne og hva paragrafen faktisk sier.

Artikkel I har i særlig grad vært anvendt av Menneskerettighetskomiteen (som overvåker Konvensjonen om sivile og politiske rettigheter), knyttet til retten til selvbestemmelse for urfolk. Når det gjelder Vest-Sahara uttalte Komiteen at de fortsatt er bekymret for mangelen på framgang for realisering av retten til selvbestemmelse for folket ('people') i Vest-Sahara. ${ }^{9}$ Menneskerettighetskomiteen fastholder at Artikkel I både gir en bakgrunn for å forstå de individuelle rettighetene i de to konvensjonene, og utgjør en viktig forutsetning 
for å nyte godt av disse individuelle menneskerettighetene. ${ }^{\mathrm{1}}$ Hvilke rettslige og politiske konsekvenser en erkjennelse av at et folk har selvbestemmelse rent faktisk vil ha, vil variere avhengig av situasjon.

Retten til selvbestemmelse gir ikke automatisk noen rett til politisk uavhengighet for et folk. En slik rett til uavhengighet har støtte i folkeretten bare dersom folket har tilhørighet til et territorium som er en koloni eller et ikke-selvstyrt område. Prosessen mot uavhengighet for befolkningen i slike territorier må bygge på prinsippene i FN-pakten og de resolusjonene som konkretiserer innholdet i FN-pakten.

Kan så saharawiene kalles et folk? Saharawiene opplever selv å være et folk med en felles identitet som er ulik marokkanerne, og hvor forankringen til

De marokkanske investeringene for $\stackrel{\circ}{\circ}$ fasilitere utvinning av ressurser er et hinder for frigjøring av territoriet.

territoriet er meget sterk..$^{\text {II }}$ De har en særegen arabisk dialekt (hassani), livsform (nomadisme) og identitet, som i særlig grad er formet av å være en spansk koloni, og etter hvert provins. Tre franske kolonier, som etter hvert ble frigjort, omgir VestSahara. Den felles identitetsbygging utover stammenivå skjøt for alvor fart på I960- og I970-tallet. Dette er imidlertid ikke ulikt situasjonen i den arabiske eller den afrikanske verden, som tradisjonelt har vært fremmede for begrepene nasjon og nasjonalstat.

For det tredje er det behov for en klarere forståelse av ordlyden i artikkel I, paragraf
2. Særlig sentral er formuleringen "ikke i noe tilfelle må et folk bli berøvet sitt eget eksistensgrunnlag". Retten til tilfredsstillende levestandard, inklusive mat, er av de sentrale menneskerettigheter som kan trues dersom eksistensgrunnlaget berøves.

Finnes det ytterligere kriterier for å skille mellom ressurser, knyttet til hvorvidt de utgjør et eksistensgrunnlag eller ikke? Det kan argumenteres for at begrepet "eksistensgrunnlag" ikke bare kan forbeholdes de ressursene som er for direkte menneskelig konsumpsjon. Også mineraler som kan selges og dermed generere kapital, kan representere eksistensgrunnlag. Uten noen inntekter fra slike mineralressurser eller eventuelt oljeressurser blir det umulig å sikre det bredere eksistensgrunnlaget. Det synes derfor ikke hensiktsmessig å skille mellom de ulike ressursene ut fra hvilken direkte betydning disse ressursene har for et folks eksistensgrunnlag.

To ressurser vil nå bli nærmere omtalt, nemlig fisk og olje, som i særlig grad er relevant innenfor havretten. Samtidig er det sentralt å kjenne til at fosfat fortsetter å være en viktig ressurs, ${ }^{\mathrm{I} 2}$ og uthenting av denne ressursen, i strid med saharawienes ønsker, må også forstås å være i strid med folkeretten utifra samme argumentasjon.

\section{Fiskeriavtalen mellom EU og Marokko}

Med utgangspunkt i fiskeriavtalen mellom EU og Marokko vil det nå bli analysert hvorvidt det saharawiske folkets interesser er blitt sikret slik det er nedfelt i Resolusjon III fra Havrettskonferansen. Mengden av fisk som blir levert på havna i den okkuperte vest-sahariske byen Laayoune utgjør

Nedskutt marokkansk fly i Vest-Sahara. 


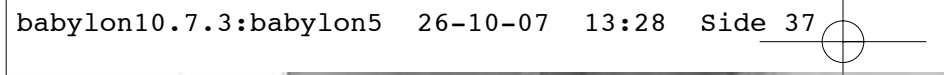
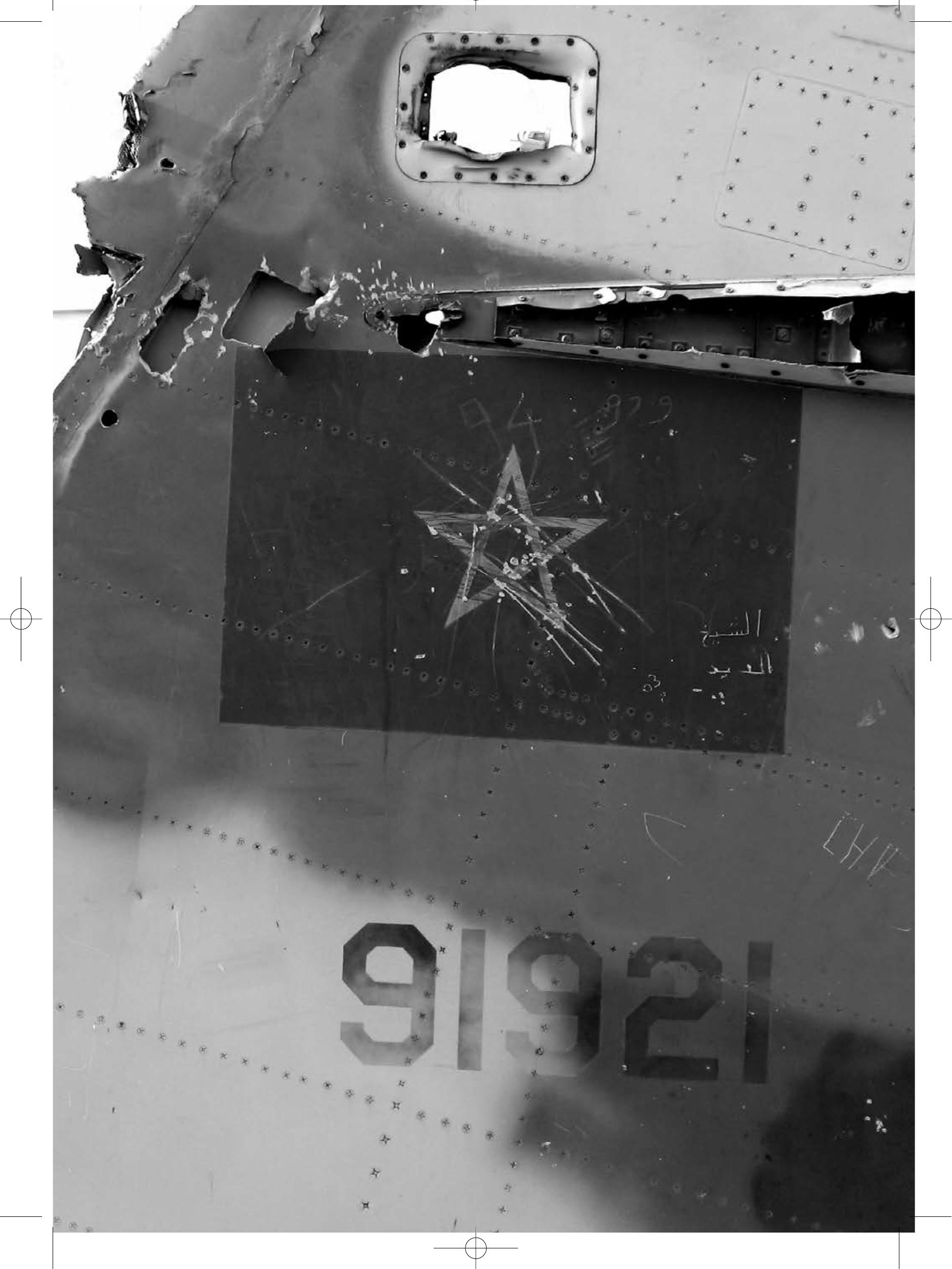
alene rundt 40 prosent av den registrerte marokkanske fiskefangsten. ${ }^{\mathrm{I} 3}$ Dette gjør det overveiende sannsynlig at over halvparten av den fisken som fanges utenfor kysten av det terrirotiet som Marokko effektivt kontrollerer, er fanget utenfor kysten av VestSahara.

Etter å ha passert fiskerikomiteen og Europaparlamentet, ble fiskeriministrene i EUs medlemsstater den 22. mai 2006 enige om en fiskeriavtale med Marokko. Avtalen gir II9 fiskebåter fra EU-stater, de fleste av disse spanske, adgang til "havet under Marokkos suverenitet og jurisdiksjon." Denne tvetydige formuleringen tolkes av partene å omfatte Vest-Sahara. Også tidligere avtaler mellom EU og Marokko inkluderte Vest-Sahara med bruk av liknende formuleringer.

Forsøkene på å ekskludere havet utenfor Vest-Sahara fra denne avtalen førte ikke fram. I løpet av prosessen med avtalen ble flere argumenter framsatt av ulike representanter fra EU. EUs argumenter skal nå presenteres og analyseres.

EUs fiskerikommisær Joseph Borg uttalte i februar 2006 at avtalen var i samsvar med FNs juridiske utredning fra 2002. ${ }^{14}$ Dette blir imøtegått av forfatteren bak FNs juridiske betenkning, Hanas Correll. I et intervju i etterkant av EUs beslutning, der han kommenterte at Sverige, som eneste land, hadde stemt imot EUs Fiskeriavtale med Marokko, sa han: "[de svenske protestene] er faktisk konsistente med det synspunktet jeg uttrykte i en erklæring jeg avga til Sikkerhetsrådet da jeg var leder av FNs juridiske kontor." ${ }^{5}$

I februar 2006 avga EU sin egen juridiske utredning der det vises til FNs juridiske utredning fra 2002, og hvor det understrekes at "utvinning av ressurser i ikke-selvstyrte områder er i strid med internasjonal rett dersom slik utvinning ikke respekterer interessene og ønskene til folket i ikke-selvstyrte områder." ${ }^{\text {16 }}$ To avsnitt senere sies det at det "ikke kan utelukkes at Marokko ikke vil etterleve sine folkerettslige forpliktelser vis-à-vis folket $i$ Vest-Sahara."

Denne påstanden ignorerer det som har vært Marokkos faktiske politikk til i dag. Det er lite som tyder på at Marokko vil legge til rette for en fiskeripolitikk som utformes sammen med og i samsvar med ønskene til den rettmessige representanten for det saharawiske folket. Videre presiserer ikke avsnittet at det utelukkende er den tidligere kolonibefolkningen (saharawiene) som har rettigheter knyttet til naturressursene, ikke dagens befolkning i territoriet, som for en stor del består av marokkanske bosettere. Siden saharawiene representerer en svært liten andel av dem som er fiskere i Vest-Sahara, er det liten sannsynlighet for at saharawiene vil ha noen som helst fordel av denne avtalen.

Det kan også hevdes at Fiskeriavtalen mellom EU og Marokko representerer en de facto anerkjennelse av Marokkos fortsatte okkupasjon av Vest-Sahara. Det EU har gjort er å inngå en avtale som også gjelder et område hvor Marokko ikke har noen territoriell rettslig status. Dette betyr at Marokko ikke har noen juridisk kompetanse til å inngå noen rettslige avtaler vedrørende dette territoriet. Det heter i pressemeldingen fra det norske finansdepartementet hvor det bekjentgjøres at KerrMcGee skal utelukkes fra Petroleumsfondets investeringsunivers: "Marokko har i en årrekke, til tross for sterk fordømmelse fra FN, okkupert Vest-Sahara. Kerr-McGee legger etter rådets vurdering til rette for 
Marokkos mulige utnyttelse av naturressursene i området. Rådet anser slik virksomhet som et 'særlig grovt brudd på grunnleggende etiske normer' blant annet fordi dette kan bidra til å legitimere Marokkos suverenitetskrav og dermed undergrave FNs fredsprosess." ${ }^{\text {"7 }}$

EU-kommisjonen hevdet flere ganger at det er Marokko, og ikke Spania, som har det administrative ansvaret i okkupert Vest-

Det kan hevdes at fiskeriavtalen mellom EU og Marokko er en de facto anerkjennelse av okkupasjonen.

Sahara. Det er særlig bekymringsfullt at dette synspunktet er hevdet av Spania, i første rekke fra fiskeriminister Miguel A. Moratinos, som viser til Madridavtalen fra I975 for å grunngi sitt synspunkt. ${ }^{18}$ Verken Madridavtalen eller andre avtaler har formelt overdratt det administrative ansvaret til Marokko. Madridavtalen ble inngått i strid med generelle prinsipper for dekolonisering, siden den delte et tidligere koloniterritorium uten at kolonibefolkningen hadde fått anledning til å uttrykke sin mening. Den er også i strid med den rådgivende uttalelsen fra Den internasjonale domstolen i Haag fra I6. oktober I975. ${ }^{\text {19 }}$

Derfor, ut fra et folkerettslig perspektiv og i samsvar med generelle EU-posisjoner vedrørende Vest-Sahara, er det to løsninger: Fiskeriavtalen mellom EU og Marokko revideres for å sikre at det bare er havressurser under Marokkos suverenitet som omfattes av avtalen. Eller så er alternativet å si opp hele fiskeriavtalen siden den bygger på et feil premiss om at Marokko har juridisk kompetanse til å inngå en avtale om ressursutvinning uten at det saharawiske folket har vært konsultert.

Her ser vi altså at det saharawiske folkets interesser ikke er ivaretatt, slik det er forutsatt at skal skje dersom ressursutvinning skjer i ikke-selvstyrte områder. Prinsippet om at det ikke-selvstyrte folkets interesser skal tas hensyn til er blitt oversett. Dette skjer selv om et premiss for utredningen fra EUs juridiske kontor er at "utvinning av ressurser i ikke-selvstyrte områder er i strid med internasjonal rett dersom slik utvinning ikke respekterer interessene og ønskene til folket i ikkeselvstyrte områder."

Forfatteren er ikke kjent med at FN offisielt har reagert på EUs juridiske utredning. Hans Corrells uttalelser kan ikke forstås å representere $\mathrm{FN}$, men har likevel stor betydning siden det var Correll som i 2002 var ansvarlig for FNs juridiske utredning.

\section{Hva indikerer olje- og gassavtalene?}

Som en interessant kontrast til fiskeriavtalen, vil lisensavtalene inngått mellom åtte oljeselskaper og myndighetene i Den saharawiske arabiske demokratiske republikk bli analysert. Avtalene bygger på en erkjennelse av at ressursene ikke skal utnyttes uten at dette skjer til fordel for den saharawiske befolkningen, i samsvar med synspunktene til deres valgte representanter. Vi husker at Havrettskonvensjonens artikkel 77 sier at ingen kan undersøke kontinentalsokkelen og utnytte dens naturforekomster uten kyststatens samtykke. Mengden av olje og gass på Vest-Saharas territorium og kontinentalsokkel er fortsatt vanskelig å beregne, men det faktum at det antakelig finnes håndterbare mengder $\mathrm{av}$ olje og gass regnes å ville "vanskeliggjøre 
enhver løsning." ${ }^{\text {гі }}$ Interessen fra oljeselskapene for å utforske oljeforekomster i og utenfor kysten av Vest-Sahara var merkbar på I960- og 70-tallet, men ingen virksomhet ble startet. ${ }^{22}$ De første letekontraktene ble inngått i 200I, mellom det marokkanske statsoljeselskapet ONHYM og respektive Kerr-McGee og Total (tidligere TotalFinaElf), og i 2002 mellom petroleumsforvaltningen i SADR og Fusion Oil\&Gas.

Et sammenfall av to hendelser inntraff våren 2006. For det første ble kontrakten med ONHYM om virksomhet i VestSahara avsluttet av Kerr-McGee. For det andre ble hele åtte nye kontrakter inngått med SADR. ${ }^{23}$ Disse siste kontraktene har en bestemmelse som sier at oljeutvinning først skal skje når man har funnet en løsning på konflikten. Dette formuleres slik av selskapet EnCore Oil, basert i Storbritannia: "Ingen utvinning av Vest-Saharas ressurser offshore vil ble gjennomført før den aktuelle konflikten er blitt løst." ${ }^{24} \mathrm{Et}$ annet selskap som har inngått en tilsvarende avtale bruker følgende formulering: "vellykket løsning hva gjelder territoriets suverenitet." 25

Ved at lisensavtalene understreker at leting og utvinning kun skal skje etter at en territoriell løsning er funnet, må det hevdes at disse åtte oljeselskapene opererer innenfor internasjonal rett, som gjort rede for av FNs tidligere under-generalsekretær for juridiske saker. ${ }^{26}$

Samtidig er ikke alle formuleringer i de åtte avtalene like heldige. Som eksempel kan vises til Europa Oils hjemmeside, hvor det vises til områder som i dag er "styrt" ("governed") av Marokko. ${ }^{27}$ Selv om dette ikke er en presis formulering, er den bedre enn formuleringer som forsøker å gi
Marokko "ansvaret for administrasjonen" i de samme områdene.

Olje- og gassavtalene er viktige på tre måter. For det første er de inngått med representanter for saharawiene. For det andre er de formulert på måter som gir saharawiene rett til å fatte alle beslutninger vedrørende utvinning av ressurser i området. For det tredje uttrykker de at ingen utvinning vil foregå før en territoriell løsning blir funnet.

Samtidig er ikke lisensavtalene tydelige på hva en akseptabel løsning faktisk innebærer. Å “løse en disputt” er forskjellig fra en "vellykket løsning hva gjelder territoriets suverenitet". Den siste formuleringen

\section{ram \\ EU bidrar til å legitimere tappingen av fiskeressursene fra Vest-Saharas kyst.}

må sies å være mer ambisiøs enn den første. Det første selskapet som inngikk en avtale med SADR, Fusion Oil\&Gas, har uttrykt eksplisitt at de forventer "en rettferdig løsning som tillater saharawiene å kontrollere sitt eget territorim. ${ }^{28}$ En slik formulering er mer direkte enn ordlyden valgt av de åtte selskapene som inngikk kontrakter med SADR i 2006, men også disse peker i samme retning.

Foreløpig har det ikke skjedd en utvinning av olje og gass som har satt til side det saharawiske folkets interesser. De avtalene som er inngått med petroleumsmyndighetene til SADR og ni oljeselskaper, kan likevel foreløpig ikke iverksettes, så lenge Marokko de facto kontrollerer store deler av territoriet og kysten utenfor. 
Det er fremdeles ingen konsenus i oljebransjen for hvordan forholde seg til konflikten mellom Vest-Sahara og Marokko. Det er også inngått avtaler mellom Marokko og vestlige selskaper som legger grunnen for at en slik utvinning kan finne sted. Det ble for eksempel inngått to nye kontrakter mellom marokkanske myndigheter og vestlige oljeselskaper i 2006, både for virksomhet på Vest-Saharas landterritorium og utenfor Vest-Saharas kyst. ${ }^{29}$ Slik avtalene er formulert, vil dette skje uten samtykke fra kyststaten VestSahara, i samsvar med prinsippet om at det er interessene til folket i det ikke-selvstyrte området som skal ivaretas.

\section{Konklusjon}

Som vi har sett er det ulike scenarier for ressurskontroll, avhengig av om en ser på situasjonen innenfor fosfat og fiske, eller innenfor olje. Årsakene til at det er innenfor oljeutvinning vi har sett de største endringene, er følgende: For det første er ikke oljeutvinning en pågående virksomhet i Vest-Sahara, i motsetning til fiske. Det er uvisst om det faktisk finnes drivverdig olje på Vest-Saharas territorium eller på kontinentalsokkelen. For det andre har de selskapene som har inngått avtaler med SADR ikke foreløpig foretatt noen investeringer, men de posisjonerer seg for en framtidig situasjon. Disse selskapene kan la denne opsjonen vente mens de orienterer seg mot andre områder hvor utvinning kan starte snart. Når det gjelder fisk, er situasjonen annerledes siden næringslivet i Europa er avhengige av Marokkos (og Vest-Saharas) fiskeressurser, særlig fiskeindustrien i Spania og Portugal. En tilsvarende avhengighet gjelder ikke for eventuelle oljeforekomster.
Samtidig er det grunn til å tro at oppmerksomheten knyttet til ressursutvinning fra Vest-Sahara, har skapt generelt større bevissthet, både blant diplomater og næringslivsledere, ${ }^{30}$ om hva som er de folkerettslige regler. De sentrale reglene finnes i de to menneskerettighetskonvensjonene, FN-pakten og resolusjon III fra Havrettskonferansen.

Artikkel I i FNs Konvensjon om økonomiske, sosiale og kulturelle rettigheter og FNs Konvensjon om sivile og politiske rettigheter stiller opp de mest forpliktende reglene for statene, mens Kapittel XI i FN-pakten regulerer både de substansielle og prosessuelle forpliktelsene for en stat som har ansvaret for administrasjonen av et ikke-selvstyrt område. Resolusjonen fra Havrettskonferansen er mer en presisering av forpliktelser som allerede gjelder etter internasjonal rett.

Løsningene er i prinsippet enkle, men vil kreve politisk vilje for å kunne bli gjennomført. For det første kan EU velge å revidere fiskeriavtalen for å holde Vest-Sahara utenfor avtalen. Dette er gjort i USAs frihandelsavtale med Marokko..$^{31}$ Det kan sette presedens for EU.

For det andre må internasjonalt press utøves mot Marokko for å sikre tilslutning og lojal oppfølging av den fredsavtalen som allerede er vedtatt med enstemmighet i FNs Sikkerhetsråd, den såkalte Baker IIplanen. ${ }^{32}$ Sikkerhetsrådet vedtok planen gjennom resolusjon I495 av 31. juli 2003 , som sier i avsnitt I: "supports strongly the efforts of the Secretary-General and his Personal Envoy and similarly supports their Peace plan for self-determination of the people of Western Sahara."

For det tredje, mens det arbeides med å finne en løsning på konflikten i tråd med 
internasjonal rett og i samsvar med Sikkerhetsrådets resolusjon I495, bør det ikke finne sted ressursutvinnelse i det okkuperte territoriet. Erfaring viser at en slik utvinnelse, dersom den forekommer, vil finne sted uten tilslutning fra saharawiene eller deres valgte representanter.

Utifra den tolkning av EUs fiskeriavtale med Marokko som er presentert her, bidrar EU til å legitimere tappingen av fiskeressursene fra Vest-Saharas kyst, og dette arbeidet føres an av Spania.

Olje- og gassavtalene, på den andre siden, representerer viktige skritt framover på veien mot å sikre saharawiene råderett over ressursene som befinner seg på deres territorium og langs deres kyst. Disse kan legge til rette for at ressursutvinningen kan skje på en måte som sikrer saharawienes interesser og rettigheter, slik folkeretten forutsetter.

\section{$\cdot f \cdot$}

I Resolusjon A/Res/34/37 (I979): 'Question of Western Sahara',

2 Resolusjon A/RES/I5I4 (XV) 'Declaration on the granting of independence to colonial countries and peoples' sier $\mathrm{i}$ avsnitt 5: 'Immediate steps shall be taken, in Trust and Non-Self-Governing Territories or all other territories which have not yet attained independence, to transfer all powers to the peoples of those territories, without any conditions or reservations, in accordance with their freely expressed will and desire, without any distinction as to race, creed or colour, in order to enable them to enjoy complete independence and freedom.'

3 Resolusjon A/RES/I54I (XV) 'Principles which should guide members in determining whether or not an obligation exists to transmit the information called for under Article 73 e of the Charter', prinsipp VII og IX.

4 Republikken SADR ble erklært den 28. februar I976, etter at den siste spanske militære tilstedeværelsen var avviklet. I dag er Republikken fullt medlem av Den afrikanske union (AU).

5 Se: http://www.regjeringen.no/nb/sub/Styrer-rad-utvalg/ etikkradet/Tilradninger/Tilradninger/Tilradning-omuttrekk-av-Kerr-McGee.html?id=425309, avgitt I2. april 2005, lesedato Io. september 2007.

6 Resolusjon A/RES/328I (XXIX) ('Charter of Economic Rights and Duties of States'), avsnitt I6.2.
7 Shelley, Toby: Endgame in Western Sahara: What Future for Africa's Last Colony? London: Zed Books, 2004:36.

8 France Libertés-AFASPA [Association Française d'Amitié et de Solidarité avec les Peuples d'Afrique] (2003) Report: International Mission of Investigation in Western Sahara 28 October to 5 November 2002, 32-33; http://www. arso.org/FLioiroze.pdf>, lesedato 25. mai 2007.

9 CCPR/CO/82/MAR: Concluding observations of the Human Rights Committee: Morocco, vedtatt I. desember 2004, avsnitt 8. Tilsvarende uttrykte Komiteen for økonomiske, sosiale og kulturelle rettigheter i sin siste gjennomgang av Marokko (E/C.I2/I/Add.55: Concluding Observations of the Committee on Economic, Social and Cultural Rights : Morocco, vedtatt I. desember 2000) i avsnitt I3: "With regard to the situation in the Western Sahara, the Committee regrets that there has not been a definite solution to the question of self-determination."

Io FNs Menneskerettighetskomité: General comment I2: The right to self-determination of peoples (Article I) (Twenty-first session of the Human Rights Committee), I984, avsnitt I: "The right to self-determination is of particular importance because its realization is an essential condition for the effective guarantee and observance of individual human rights, and for the promotion and strengthening of those rights."

II Kirkerud, Eirik Hjort: Our homeland is not our destination, it's our destiny: diaspora og nasjonsbygging blant vest-sahariske flygtninger i Algerie, Hovedoppgave i sosialantropologi, Oslo: Universitetet i Oslo, 2004.

I2 Ifølge US Geological Survey sitter Marokko og VestSahara på 50 prosent av verdens erkjente fosfatreserver og 6o prosent av verdens potensielle forekomster: http://minerals.usgs.gov/minerals/pubs/commodity/ phosphate_rock/phospmcs96.pdf, lesedato 25. mai 2007 og http://www.sei.se/dload/2004/Rosemarin_NP.pdf, lesedato 25 . mai 2007.

I3 Shelley (note 7): 75. Andre kilder bekrefter dette tallet.

I4 Gjengitt i pressemelding fra 29. mai 2006: 'New EU Morocco fisheries agreement in breach of international law'; http://www.fishsec.org/article.asp?CategoryID=I\& ContextID=I3, lesedato 25 .mai 2007 .

I5 Sahara Update: EU accepted agreement in occupied waters: Interview with the UN's former legal chief, Hans Corell', Swedish Radio 22.mai 2006; http://groups. yahoo.com/group/Sahara-Update/message/I758 (egen oversettelse), lesedato 25. mai 2007.

I6 Europaparlamentet ('Legal Service') Legal opinion: Proposal for a Council Regulation on the conclusion of the Fisheries Partnership Agreement between the European Community and the Kingdom of Morocco - Compatibility with the principles of international law', SJ$0085 / 06,20$ februar 2006, avsnitt 40; egen oversettelse.

I7 Finansdepartementet 2005: Første selskap utelukket fra Petroleumsfondet, pressemelding 6.juni 2005; se: http://odin.dep.no/fin/norsk/tema/statens_pensjons fond/p30005696/pressemeldinger/00607I-070638/ dok-bn.html, lesedato 25. mai 2007.

I8 Carlos Ruiz Manuel: Los Acuerdos de Madrid, inmorales, illegales y políticamente suicidas, Grupos de Estudios 
Estratégicos 2006; http://www.gees.org/articulo/2344, lesedato 25 . mai 2007.

I9 Den rådgivende uttalelsen avgitt Io. oktober I975 konkluderte slik: “...the Court has not found legal ties of such a nature as might affect the application of General Assembly resolution I5I4 (XV) in the decolonization of Western Sahara and, in particular, of the principle of self-determination through the free and genuine expression of the will of the peoples of the Territory."

20 Europaparlamentet (note I6), avnsitt 40.

2I Jensen, Erik: Western Sahara: Anatomy of a Stalemate, International Peace Academy Occasional Paper Series, Boulder, Co.: Lynne Rienner Publishers, 2005:I20 (egen oversettelse).

22 Shelley (note 7): 65.

23 SADR Petroleum Authority pressemelding I7. mars 2006: 'SADR Offshore Oil \& Gas License Awards: Successful Conclusion of the 2005 Western Sahara Licensing Oil and Gas Initiative', se: http://www.sadroilandgas.com/pdfs/permitso6.pdf, lesedato 25. mai 2007.

24 'Western Sahara'; http://www.encoreoil.co.uk/pages/con tent/index.asp?PageID=53 (egen oversettelse), lesedato 25. mai 2007 .

25 'Operations in Western Sahara'; http://europaoil.co.uk (egen oversettelse - besøkt 25. mai 2007)

26 S/2002/I6I, Letter dated 29 January 2002 from the Under-Secretary-General for Legal Affairs, the Legal Counsel, addressed to the President of the Security Council.

27 Se Europa Oil (note 25).

28 PESA News: Fusion provides $200,000 \mathrm{~km} 2$ study for new African acreage chance; http://www.pesa.com.au/Publi cations/pesa_news/april_03/sahara.htm, lesedato 25. mai 2007.

29 De to kontraktene ble inngått henholdsvis i mai 2006 mellom ONHYM og Kosmos Energy; se: http://www.vestsahara.no/files/pdf/onhym_agreements_2006.pdf, lesedato 25. mai 2007, og i desember 2006 mellom det marokkanske selskapet San Leon og GB Oil and Gas Ventures Limited $(30 \%)$ og Island Oil \& Gas plc $(20 \%)$; se: http://www.islandoilandgas.com/default.asp?docId= I2442\&newsItem $=\mathrm{I} 2760$, lesedato 25 . mai 2007.

30 Brennpunkt-dokumentaren 'Diplomatisk dobbeltmoral', vist 2. mai 2005, se: http://www.nrk.no/programmer/tv/ brennpunkt/4717346.html (lesedato 25.mai 2007) illustrerer manglende innsikt både hos den norske ambassadøren til Marokko og fiskeforedlingsbedrifter.

3I Robert Zoelick: Brev til Kongressmedlem Joseph R. Pitts av 20. juli 2004: http://www.house.gov/pitts/temporary/ 0407igl-ustr-moroccoFTA.pdf, lesedato 25. mai 2007.

32 Fredsplanen for selvbestemmelse for folket i Vest-Sahara finnes som anneks II til Sikkerhetsrådsrapporten $\mathrm{S} / 2003 / 565$. Det er verdt å merke seg at Baker II-avtalen gir betydelige innrømmelser til Marokko, blant annet ved å gi stemmerett $\mathrm{i}$ en folkeavstemming til alle som befant seg på territoriet pr 3I.I2.99 - også marokkanske boset- tere. Avtalen er imidlertid ikke så velvillig overfor Marokko som Baker I-avtalen, en avtale som ble avvist av FNs Sikkerhetsråd. 